\title{
Sistem Informasi Berbasis Web untuk Membantu Kegiatan Tracer Study Program Diploma Institut Pertanian Bogor
}

\author{
Sofiyanti Indriasari, S.Kom \\ Program Keahlian Manajemen Informatika ProgramDiploma IPB
}

Diterima 31 Agustus 2012/ Disetujui 15 Oktober 2012

\begin{abstract}
IPB Diploma Program has alumni that are broadly spread throughout Indonesia. Tracer study is always conducted progressively each year. Other methods conducted include questionaire via post, email, mailing list, graduation ceremony, alumni meeting, etc. By evaluating tracer study, some innovations are needed to increase its activities. Regarding the advancement of web based technology and internet media that has gone significant in Indonesia, one innovation for tracer study is a website facility which can be accessed by alumni, assumed that all alumni have internet access. IPB Diploma Program Tracer Study Information System is built on the basis of web technology. This system is aimed to increase data collectivity and gives out information, in form of report with default format prepared by IPB Diploma Program. This research yields an IPB Diploma Program Tracer Study Information System which already helps alumni and the data collection of user satisfaction. IPB Diploma Program Tracer Study Information System has a feature to show report which makes alumni information and user satisfaction data to be easily obtained. The information shown is in the form of graphic and tabular data. On the other hand, this system is also equipped with alumni searching facility to track whether an alumni has already participated in tracer study activity.
\end{abstract}

Keyword : Information system, tracer study, website facility

\section{PENDAHULUAN}

\section{Latar Belakang}

Salah satu indikator keberhasilan pendidikan tinggi adalah aspek relevansi. Pada aspek relevansi ini, perguruan tinggi dituntut mampu menghasilkan lulusan yang memiliki daya saing dan siap berkiprah dalam pembangunan. Seberapa besar dan sejauh mana lulusan perguruan tinggi mampu berkiprah dalam pembangunan. Hampir semua perguruan tinggi telah berupaya melakukan penelusuran terhadap lulusannya (tracer study), namun hasil yang diperoleh sebagian besar belum memuaskan. Padahal, hasil dari tracer study tersebut sangat dibutuhkan oleh setiap perguruan tinggi untuk mengetahui keberhasilan proses pendidikan yang telah dilakukan terhadap anak didiknya. Bahkan dalam program hibah kompetisi maupun akreditasi selalu mempersyaratkan adanya data hasil tracer study tersebut melalui parameter masa tunggu lulusan, presentase lulusan yang sudah bekerja, dan penghasilan pertama yang diperoleh.

Program Diploma Institut Pertanian Bogor memiliki alumni yang tersebar di berbagai daerah di Indonesia. Program Diploma Institut Pertanian Bogor terus berusaha melakukan tracer study secara berkelan-jutan setiap tahunnya. Cara yang dilakukan diantaranya adalah dengan menyebarkan kuisioner melalui pos, email, mailinglist, acara wisuda, pertemuan alumni, dan lain sebagainya. Selain itu, dilakukan wawancara dengan alumni secara langsung ataupun melalui telepon. Dengan melihat kegiatan tracer study Program Diploma IPB tersebut, sehingga dirasa masih perlu dilakukan inovasi untuk meningkatkan kegiatan tracer study. Mengingat perkembangan teknologi berbasis web 
dan media internet yang kian menjamur dikalangan masyarakat Indonesia, salah satu inovasi yang bisa dilakukan untuk kegiatan tracer study adalah dengan mengembangkan suatu sarana berupa website yang bisa diakses oleh alumni, dengan anggapan bahwa internet sudah dijangkau oleh sebagian besar alumni.

Sistem Informasi berbasis web untuk membantu kegiatan tracer study bertujuan untuk menambah sarana kegiatan tracer study dalam hal pengumpulan data serta memberikan informasi berupa laporan hasil pendataan tracer study sesuai dengan format yang telah ditentukan oleh Program Diploma IPB. Selain itu, sistem informasi yang akan dibuat diharapkan dapat membantu kegiatan pengumpulan data kepuasan pengguna terhadap lulusan Program Diploma IPB.

Tujuan dari penelitian ini adalah :

a. Membuat suatu sarana untuk membantu kegiatan tracer study Program Diploma IPB yang berupa sistem informasi berbasis web yang ditujukan untuk para alumni dan pengguna dari lulusan Program Diploma IPB.

b. Menyediakan laporan hasil dari pendataan tracer study sesuai dengan format dan variabel yang ditentukan oleh Program Diploma IPB.

\section{METODOLOGI}

Bahan

a. Spesifikasi komputer yang digunakan pada penelitian ini :

- Prosesor : Intel Core 2 Duo Processor T5600

-Memory : 2 GB

-Harddisk untuk penyimpanan aplikasi : $800 \mathrm{MB}$

- Sistem operasi : Windows

b. Software pendukung untuk membangun Sistem Informasi Tracer Study Program Diploma IPB

-XAMPP (Apache, PHP, MySql)

- Macromedia Dreamweaver

-Browser : Google Chrome, Internet Explorer, Mozilla Firefox

c. Modem

d. Harddisk 500Gb

e. Printer dan Catridge

f. Data : Format Kuisioner \& Kebutuhan Informasi Tracer Study Program Diploma IPB

\section{Metode}

Metode penelitian ini menggunakan metode pengembangan perangkat lunak model prototipe. Pressman (2005) menyatakan bahwa seringkali seorang pelanggan mendefinisikan serangkaian sasaran umum bagi perangkat lunak, tetapi tidak mengidentifikasi kebutuhan input, pemrosesan, ataupun output detail. Dalam situasi seperti ini salah satu model yang cocok digunakan adalah model prototipe (prototyping paradigm). Tahapan dalam model prototipe dapat dilihat pada Gambar 1. 


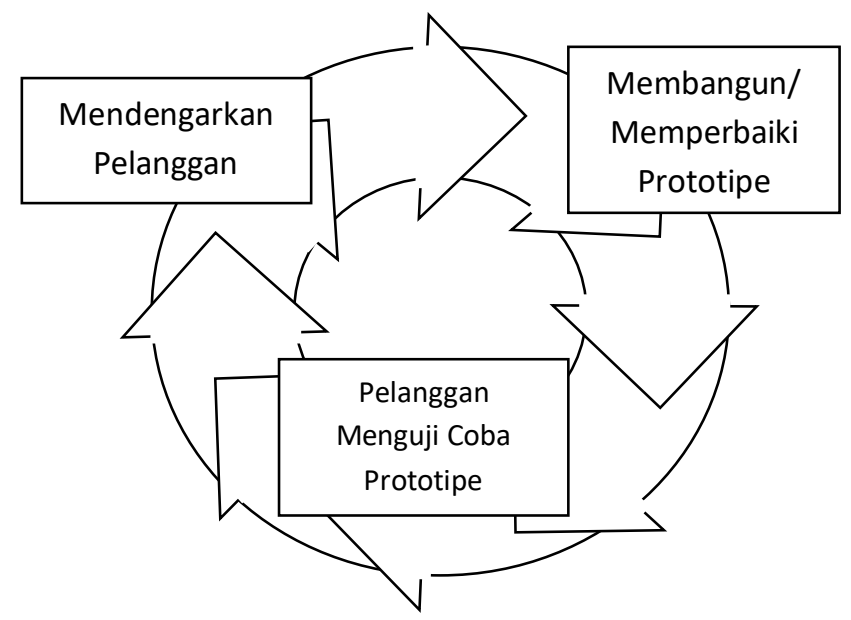

Gambar 1 Metode Prototipe

\section{HASIL DAN PEMBAHASAN}

Tahapan penelitian Sistem Informasi Berbasis Web untuk Membantu Kegiatan Tracer Study Program Diploma Institut Pertanian Bogor dilakukan sesuai dengan metode pengembangan perangkat lunak model prototipe yang tercantum dalam Pressman (2005). Berikut ini adalah tahapan-tahapan yang telah dilakukan :

1. Mendengarkan Pelanggan

Tahap Mendengarkan pelanggan adalah tahapan mempelajari proses bisnis yang dibutuhkan pelanggan. Proses bisnis yang sesuai dengan kebutuhan pelanggan dapat diketahui dengan melakukan pengamatan proses bisnis, wawancara, dan menumpulkan data yang terkait. Hasil dari pengamatan proses bisnis, wawancara dan pengumpulan data digunakan untuk proses analisis sehingga akan mendapatkan rumusan yang tepat.

a. Pengamatan Proses Bisnis dan Wawancara

Untuk mempelajari proses bisnis yang dilakukan dalam kegiatan tracer study, penulis ikut serta dalam pelaksanaan kegiatan tracer study. Pada pelaksanaan tersebut didapatkan mekanisme awal proses kegiatan tracer study yaitu dengan melakukan pengumpulan data alumni dan data pengguna melalui telepon, email, dan pertemuan langsung. Selain itu, penulis juga melakukan wawancara dibeberapa kesempatan kepada pihak terkait dengan cara mengajukan pertanyaan-pertanyaan. Hasil dari wawancara tersebut digunakan sebagai penunjang untuk memahami proses bisnis kegiatan tracer study di Program Diploma IPB.

b. Pengumpulan Data

Metode Pengumpulan data dilakukan dengan mempelajari beberapa referensi yang diperoleh dari internet dan memanfaatkan hasil dari kegiatan Pengamatan Proses Bisnis yang telah dilakukan sebelumnya. Hasil dari kegiatan Pengamatan Proses Bisnis di antaranya adalah pengetahuan tentang kebutuhan data yang digunakan untuk pembuatan web tracer study yaitu sebagai berikut:

- Format Kuisioner Alumni

- Format Kuisioner Pengguna

- Format Laporan Hasil Tracer Study 
c. Model Analisis

- Format Laporan Hasil Pendataan Kepuasan Pengguna

Model analisis menurut Pressman 2005 terdiri dari elemen-elemen berikut ini:

- Deskripsi Objek Data

Deskripsi objek data adalah proses menggambar objek yang berhubungan langsung dengan sistem atau perangkat lunak yang akan dibangun. Objek tersebut selanjutnya akan disebut sebagai entitas. Setiap entitas yang mempunyai peranan terhadap sistem memiliki relasi antara satu entitas dengan entitas lainnya. Relasi antar entitas akan digambarkan dalam Entity Relationship Diagram (ERD) . ERD untuk Sistem Informasi Tracer Study Program Diploma IPB dapat dilihat pada Gambar 2.

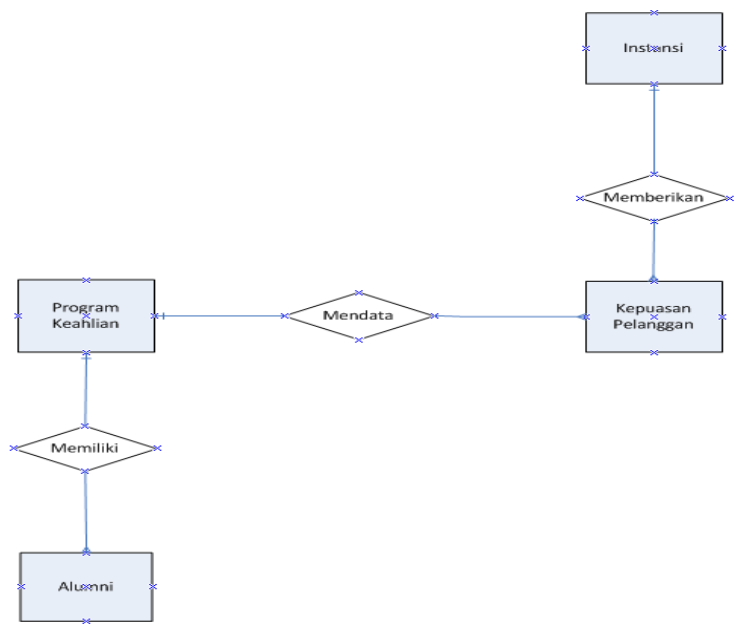

Gambar 2 ERD Sistem Informasi Tracer Study Program Diploma IPB

- Spesifikasi Proses

Spesifikasi proses adalah melakukan pemodelan fungsional sistem dan menganalisis aliran data dan informasi dalam sistem yang akan dibangun. Data Flow Diagram (DFD) digunakan untuk pemodelan fungsional sistem serta untuk menggambarkan analisis aliran data dan informasi. DFD dibagi menjadi beberapa level. DFD Level 0 disebut juga sebagai Diagram Konteks menggambar aliran data dan informasi yang masuk dan keluar dalam sistem. DFD Level 1 memperjelas Diagram Konteks yaitu dengan menggambarkan setiap proses yang ada dalam sistem. Selain itu, pada DFD level 1 juga memperjelas aliran data dan informasi yang terkait pada masisng-masing proses tersebut. Diagram Konteks Sistem Informasi Tracer Study Program Diploma IPB dapat dilihat pada Gambar 3. DFD Level 1 Sistem Informasi Tracer Study Program Diploma IPB dapat dilihat pada Gambar 4. 


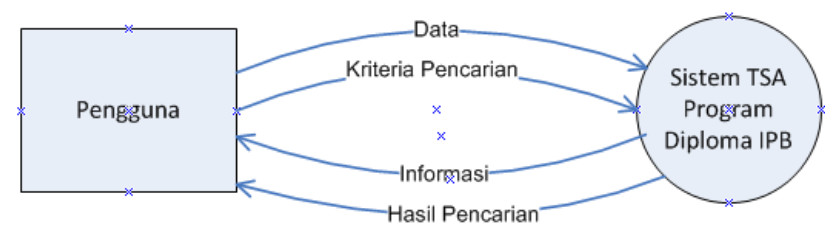

Gambar 3 Diagram Konteks

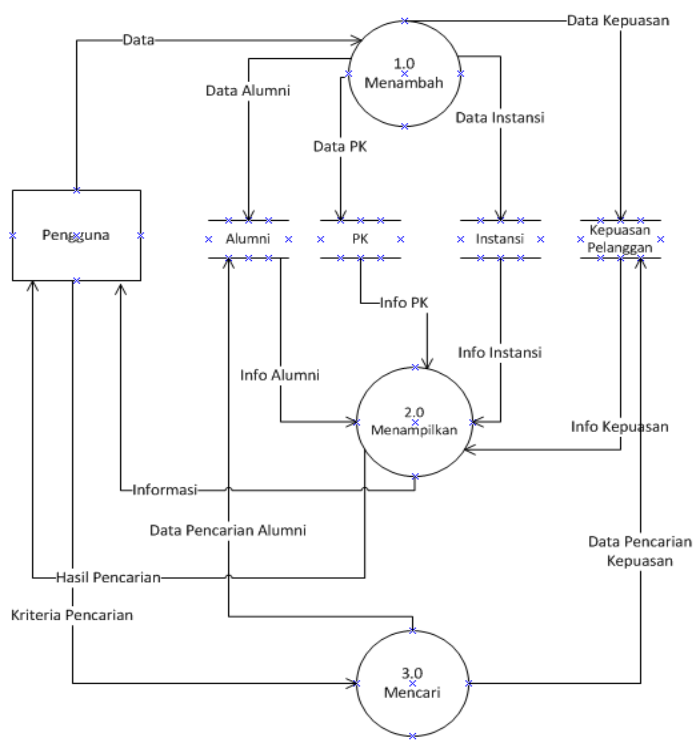

Gambar 4 DFD Level 1

2. Membangun / Memperbaiki Prototipe

Tahap membangun prototipe dilakukan dengan memetakan hasil dari model analisis ke perancangan perangkat lunak. Langkah-langkah yang dilakukan untuk memetakan hasil dari pemodelan analisis ke perancangan perangkat lunak adalah sebagai berikut:

a. Desain Data

Proses desain data adalah mengubah ERD menjadi struktur data. Struktur data adalah deskripsi dari tabel yang digunakan oleh sistem. ERD Sistem Informasi Tracer Study Program Diploma IPB dijadikan acuan untuk membentuk tabel-tabel yang akan digunakan. Deskripsi tabel pada Sistem Informasi Tracer Study Program Diploma IPB dapat dilihat pada Tabel 1 sampai dengan Tabel 4.

Tabel 1. Program Keahlian

\begin{tabular}{llll}
\hline No & Nama Field & Tipe Data & Keterangan \\
\hline 1 & PK_id & Integer & Primary Key \\
2 & Nama_PK & Integer &
\end{tabular}


Tabel 2. Alumni

\begin{tabular}{|c|c|c|c|}
\hline No & Nama Field & Tipe Data & Keterangan \\
\hline 1 & Alumni_id & Integer & Primary Key \\
\hline 2 & NIM & Varchar & \\
\hline 3 & Nama & Varchar & \\
\hline 4 & PK_id & Integer & Foreign Key \\
\hline 5 & Pembimbing & Varchar & \\
\hline 6 & Alamat_rumah & Text & \\
\hline 7 & Email & Varchar & \\
\hline 8 & Telepon & Varchar & \\
\hline 9 & Tahun_masuk & Integer & \\
\hline 10 & Tahun_lulus & Integer & \\
\hline 11 & Aktivitas & Integer & \\
\hline 12 & Kesesuaian_pendidikan & Integer & \\
\hline 13 & Jenjang_pendidikan & Varchar & \\
\hline 14 & Institusi_pendidikan & Varchar & \\
\hline 15 & Jurusan & Varchar & \\
\hline 16 & Mulai_bekerja & Integer & \\
\hline 17 & Kesesuaian_pekerjaan_pertama & Integer & \\
\hline 18 & Posisi_pertama & Varchar & \\
\hline 19 & Institusi_bekerja_pertama & Integer & \\
\hline 20 & Institusi_bekerja_pertama_lainnya & Varchar & \\
\hline 21 & Nama_institusi_pertama & Varchar & \\
\hline 22 & Gaji_pertama & Integer & \\
\hline 23 & Tahun_mulai & Integer & \\
\hline 24 & Tahun_selesai & Varchar & \\
\hline 25 & Bulan_bekerja & Integer & \\
\hline 26 & Tahun_bekerja & Integer & \\
\hline 27 & Kesesuaian_pekerjaan_sekarang & Integer & \\
\hline 28 & Bidang_institusi & Integer & \\
\hline 29 & Bidang_institusi_lainnya & Varchar & \\
\hline 30 & Posisi_sekarang & Varchar & \\
\hline 31 & Institusi_bekerja_sekarang & Integer & \\
\hline 32 & $\begin{array}{l}\text { Institusi_bekerja_sekarang_lainny } \\
\text { a }\end{array}$ & Varchar & \\
\hline 33 & Nama_institusi_sekarang & Varchar & \\
\hline 34 & Alamat_institusi & Text & \\
\hline 35 & Telepon_institusi & Varchar & \\
\hline 36 & Gaji_sekarang & Integer & \\
\hline 37 & Tanggal & Date & \\
\hline
\end{tabular}


Tabel 3. Instansi

\begin{tabular}{llll}
\hline No & Nama Field & Tipe Data & Keterangan \\
\hline 1 & Instansi_id & Integer & Primary Key \\
2 & Nama_instansi & Varchar & \\
3 & Nama_responden & Varchar & \\
4 & Jabatan & Varchar & \\
5 & Tanggal & Date & \\
\hline
\end{tabular}

Tabel 4. Kepuasan Pengguna

\begin{tabular}{llll}
\hline No & Nama Field & Tipe Data & Keterangan \\
\hline 1 & Kepuasan_id & Integer & Primary Key \\
2 & Instansi_id & Integer & Foreign Key \\
3 & PK_id & Integer & Foreign Key \\
4 & Tingkat_kepuasan & Integer & \\
5 & Variabel & Integer & \\
\hline
\end{tabular}

b. Desain Arsitektur Sistem

Desain arsitektur sistem adalah memetakan DFD menjadi struktur program. Hasil pemetaan DFD dapat dikelompokkan menjadi desain input, proses, dan output. Ketiga kelompok desain tersebut akan dijadikan sebagai pendukung dalam proses desain antarmuka. Untuk mempermudah dalam kegiatan selanjutnya, setiap proses atau fungsi yang ada dalam sistem didaftarkan dan dikodekan. Aturan pengkodean fungsi adalah sebagai berikut TSA-n, dimana $n$ menyatakan nomor fungsi dalam sistem ini. Pendaftran fungsi yang dilakukan mengacu pada DFD Level 1 Sistem Informasi Tracer Study Program Diploma IPB. Daftar fungsi Sistem Informasi Tracer Study Program Diploma IPB dapat dilihat pada Tabel 5.

Tabel 5. Daftar Fungsi

\begin{tabular}{lll}
\hline No & Kode Fungsi & Nama Fungsi \\
\hline 1 & TSA-1.0 & Memasukkan \\
2 & TSA-2.0 & Menampilkan \\
3 & TSA-3.0 & Mencari \\
\hline
\end{tabular}

c. Desain Antarmuka

Desain antarmuka mengacu pada DFD level 1 Sistem Informasi Tracer Study Program Diploma IPB dan hasil dari desain arsitektur yang sudah dilakukan sebelumnya. Desain antarmuka yang dibuat ada tiga jenis yaitu desain antarmuka input, desain antarmuka proses, dan desain 
antarmuka output. Masing contoh layout desain antarmuka tersebut secara berurutan dapat dilihat pada Gambar 5 sampai dengan Gambar 7.

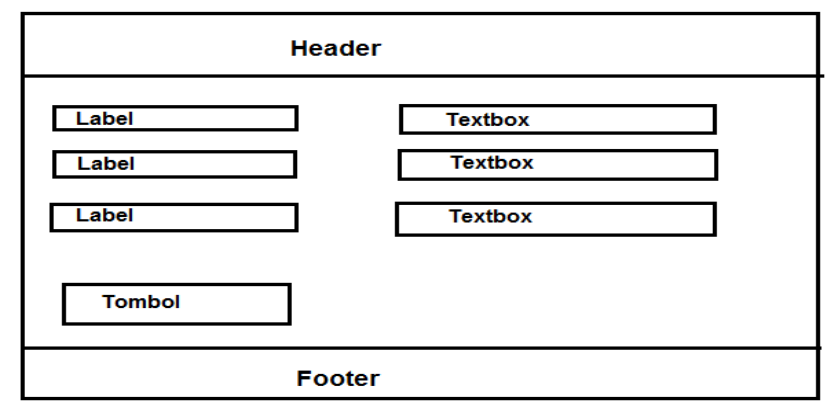

Gambar 5 Desain Antarmuka Input

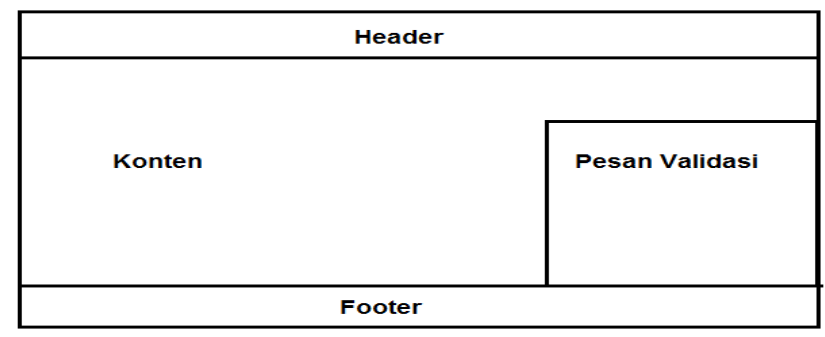

Gambar 6 Desain Antarmuka Proses

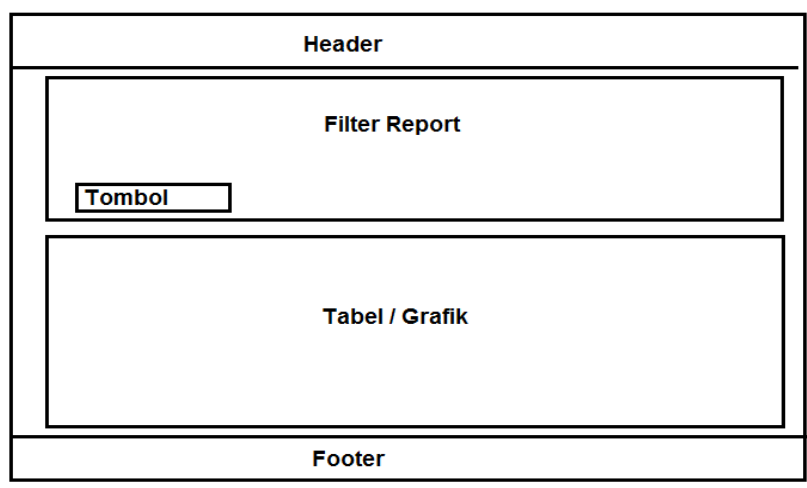

Gambar 7 Desain Antarmuka Output

d. Implementasi

Implementasi adalah proses yang menerjemahkan hasil desain ke dalam bentuk perangkat lunak secara utuh. Tahapan - tahapan implementasi yang dilakukan adalah sebagai berikut:

- Implementasi Basisdata

Implementasi basisdata adalah membuat basisdata dengan cara membuat tabel - tabel yang sudah dideskripsikan di tahapan desain ke dalam Sistem Manajemen Basis Data (SMBD). Pada penelitian ini digunakan SMBD berupa MySQL dan menggunakan tool PhPMyAdmin untuk mempermudah pembuatan basis data. Hasil implementasi basis data dapat dilihat pada Gambar 8 . 


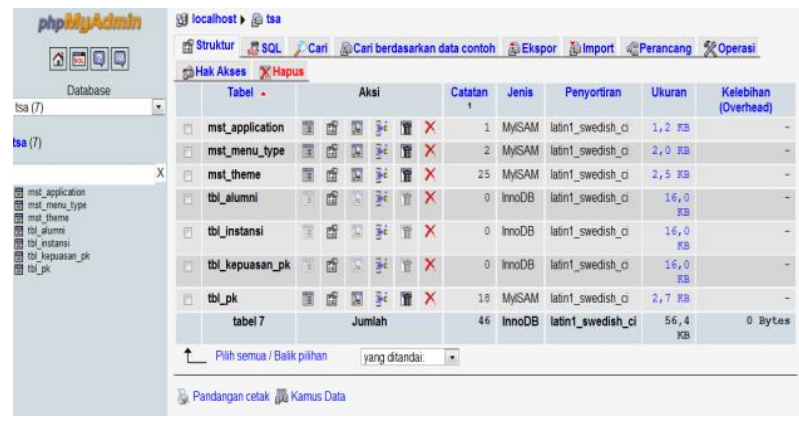

Gambar 8 Hasil Implementasi Basis Data

- Implementasi Sistem

Implementasi sistem adalah menerjemah-kan fungsi yang telah didefinisikan dapat desain sistem ke dalam bentuk kode program. Sistem Informasi Tracer Study Program Diploma IPB dibentuk menggunakan bahasa pemrograman berbasis web yaitu PHP dan menggunakan Web Server berupa Apache.

- Implementasi Antarmuka

Implementasi antarmuka adalah menerjemahkan layout yang sudah dibuat pada desain antarmuka ke dalam bentuk tampilan antarmuka sistem secara utuh. Jika antarmuka sudah dilakukan maka dapat diintegrasikan antara hasil implementasi antarmuka dan hasil implementasi sistem. Hasil implementasi antarmuka dapat dilihat pada Gambar 9 dan Gambar 10.

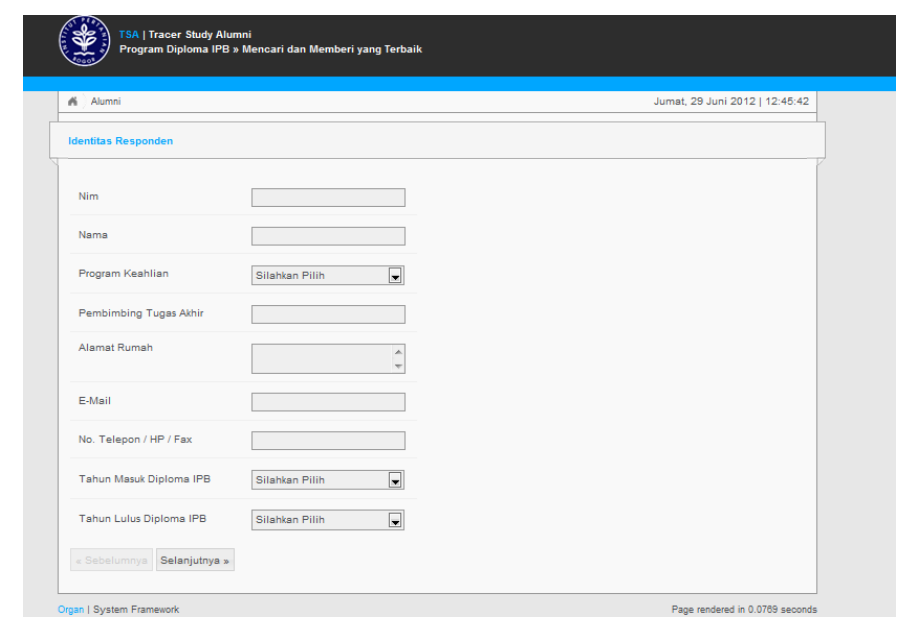

Gambar 9 Hasil Implementasi Antarmuka Input 


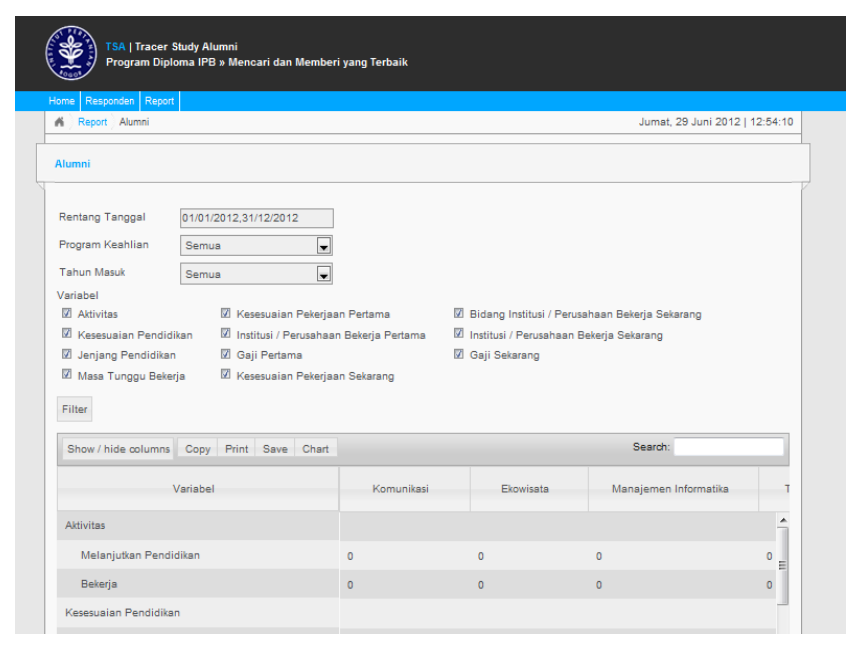

Gambar 10 Hasil Implementasi Antarmuka Output

\section{Pelanggan Menguji Coba Prototipe}

Menurut Pressman (2005) pengujian adalah proses eksekusi program untuk menemukan kesalahan sebelum digunakan oleh pengguna. Metode pengujian yang digunakan pada penelitian ini adalah metode Black Box. Metode Pengujian Black Box adalah metode pengujian yang menguji fungsionalitas sistem. Metode tersebut dilakukan untuk memastikan apakah fungsi berjalan dengan benar jika diberikan masukan yang bervariasi. Contoh hasil pengujian dapat dilihat pada Tabel 6 .

Tabel 6 Hasil Pengujian

\begin{tabular}{lllll}
\hline $\begin{array}{c}\text { Kasus } \\
\text { Uji }\end{array}$ & $\begin{array}{c}\text { Nilai } \\
\text { Input }\end{array}$ & Skenario Pengujian & $\begin{array}{l}\text { Hasil Yang } \\
\text { Diharapkan }\end{array}$ & Keterangan \\
\hline $\begin{array}{l}\text { Tambah } \\
\text { Data }\end{array}$ & Benar & $\begin{array}{l}\text { Mengisi semua form } \\
\text { dengan benar \& menekan } \\
\text { tombol kirim }\end{array}$ & $\begin{array}{l}\text { Data alumni } \\
\text { tersimpan }\end{array}$ & Sesuai \\
Alumni & & Mengisi form dengan & Menampilkan Sesuai \\
$\begin{array}{l}\text { Tambah } \\
\text { Data }\end{array}$ & Salah & $\begin{array}{l}\text { mengosongkan beberapa } \\
\text { item \& menekan tombol validasi }\end{array}$ & \\
Alumni & kirim & & \\
& & & & \\
\hline
\end{tabular}

Proses pengujian pada penelitian ini melibatkan pengembang dan pengguna. Pengembang melakukan pengujian untuk memastikan sistem berjalan dengan baik sesuai dengan proses yang ditentukan. Pengguna yang melakukan proses pengujian pada penelitian ini yaitu alumni dan petugas adminstrasi di Diploma yang terkait. Pengguna melakukan pengujian dengan cara mencoba menggunakan sistem ini untuk memberikan evaluasi dalam bentuk kritik atau saran terhadap sistem yang sudah dibuat. Hasil evaluasi dari pengguna dijadikan pertimbangan bagi pengembang untuk ditindaklanjuti dalam proses perbaikan sistem. 


\section{Simpulan}

\section{SIMPULAN DAN SARAN}

Hasil kegiatan penelitian ini adalah telah dibuat Sistem Informasi Tracer Study Program Diploma IPB yang dapat membantu kegiatan pengumpulan data alumni dan pengumpulan data kepuasan pengguna. Sistem Informasi Tracer Study Program Diploma IPB memiliki fasilitas menampilkan laporan sehingga mempermudah dalam memperoleh informasi tentang alumni dan kepuasan pengguna. Informasi yang disajikan berupa tabel dan grafik. Selain itu, sistem ini juga dilengkapi fasilitas pencarian data alumni yang berfungsi untuk mempermudah pengguna mengetahui apakah alumni yang bersangkutan sudah turut serta dalam kegiatan tracer study.

\section{Saran}

Sistem Informasi Tracer Study Program Diploma IPB diharapkan dapat terus dipantau kinerja dan penggunaanya untuk mengetahui efektifitas kegiatan pendataan alumni dan kepuasan pengguna. Selain itu, perlu dilakukan kerjasama dengan pihak akademik dalam pelaksanaannya yaitu melalui mekanisme legalisir. Legalisir diharapkan akan diproses setelah alumni yang bersangkutan telah berpartisipasi dalam kegiatan pendataan alumni serta telah membantu kegiatan pendataan kepuasan pengguna lulusan Program Diploma melalui Sistem Informasi Tracer Study Program Diploma IPB.

\section{DAFTAR PUSTAKA}

Connolly TM dan CE Begg. 1999. Database Systems, a Practical Approach to Design, Implementation, and Management. Edisi ke-2. England: Addison Wesley Longman.

McLeod R dan G Schell. 2001. Management Information System. Edisi ke-8. PrenticeHall, Inc.

Pressman RS. 2005. Software Engineering, a Practitioner's Approach. Edisi ke-6. McGraw-Hill.

Satzinger, John. Jackson, R. Burd, S. 2010. Systems Analysis \& Design In A Changing World (Fifth Edition).

Weber, Ron. 1999, Information Systems Control and Audit. New Jersey: Prentice Hall, Inc. 